\title{
Migration of Bipolar Subependymal Cells, Precursors of the Granule Cells of the Rat Olfactory Bulb, with Reference to the Arrangement of the Radial Glial Fibers
}

\author{
Kiyoshi Kishi ${ }^{1}$, Jun Yun Peng ${ }^{2}$, Sachiko Kakuta ${ }^{1}$, Kunio Murakami ${ }^{1}$, Masaru Kuroda ${ }^{1}$, \\ Shizuko Yokota ${ }^{1}$, Sadao HaYakawa ${ }^{1}$, Takashi KugE ${ }^{3}$ and Toru AsaYama ${ }^{3}$
}

Departments of Anatomy ${ }^{1}$ and Pharmacy ${ }^{3}$, Toho University School of Medicine, Tokyo, Japan; and Department of Cell Biology ${ }^{2}$, Institute of Clinical Research, Chiness-Japanese Friendship Hospital, Beijing, China

Received November 20, 1989

\begin{abstract}
Summary. In order to examine the relationship between radial glial fibers and the migrating bipolar subependymal cells which are considered to be postmitotic precursors of granule cells in the rat olfactory bulb, the arrangement of radial glial fibers along the anterior lateral and olfactory ventricles was analysed by Golgi techniques, immunohistochemical demonstration of glial fibrillary acidic protein, and electron microscopy.

In rats during their first 3 weeks of life, the bipolar subependymal cells migrate along the anterior lateral and olfactory ventricles into the center of the olfactory bulb, whereas the radial glial fibers radiating from the ventricular surface are arranged rather perpendicularly to the direction of migration of bipolar cells. Hence radial glial fibers in this region are not considered to act as guides for the rostralwards migration of subependymal cells.
\end{abstract}

Since RAKIC (1971a, b) proposed that radial glial fibers play a role in the contact guidence of migrating nerve cells, this proposition has been confirmed by many observations in the developing cerebellum (RAKIC and SIDMAN, 1973; SIDMAN and RAKIC, 1973; GARCIA-SEGRA and RAKIC, 1985), in the developing neocortex (RAKIC, 1972; PETERS and FELDMAN, 1973; SCHMECHEL and RAKIC, 1979; LEVITT and RAKIC, 1980; RAKIC, 1981; PINTO-LORD et al., 1982), in the developing archicortex (NOWAKOWSKI and RAKIC, 1979; ECKENHOFF and RAKIC, 1984), and also in cocultures with cerebellar granule cells and glial cells (HATTEN et al., 1984, 1986; EDMONDSON and HATTEN, 1987).
Our previous reports (KISHI, 1987; KURODA et al., 1988) have described the origin and migration of the immature granule cells of the rat olfactory bulb. We have described two phases of migration. The first phase is the rostralwards migration of postmitotic precursors of granule cells inside the subependymal layer; they originate in the subependymal layer around the anterior horn of the lateral ventricle, migrate through the subependymal layer along the olfactory ventricle, and reach the center of the bulb. The second phase is the radial migration from the subependymal layer to the granular layer of the olfactory bulb where immature granule cells differentiate into definitive granule cells.

The present paper deals with the migration of immature granule cells in the first phase with reference to the guiding role of radial glia in their migration. We studied the topographical relationship between migrating cells and radial glia in the rostral subependymal layer by Golgi technique, immunohistochemical demonstration of glial fibrillary acidic protein (GFAP), and electronmicroscopy.

\section{MATERIAL AND METHODS}

Wistar rats $1,3,5,10,12,15$ and 21 days of age were used in this study. Day 1 represents the day of birth.

For Golgi study, the brains of rats at 3,5,10,15 and 21 days of age were fixed with a potassium dichromate mixture (STENSAAS and STENSAAS, 1968) for 2 days at $4^{\circ} \mathrm{C}$, and immersed in $0.75 \%$ silver nitrate solution for 2 days at $4^{\circ} \mathrm{C}$. They were proces- 
sed for celloidine embedding, sectioned in coronal and sagittal planes at $100 \mu \mathrm{m}$, and mounted with Permount. Ten $\mu \mathrm{m}$ thick sections of paraffin were used to embed the brains at $3,5,10$ and 21 days and processed with $1 \%$ thionin for Nissl staining.

For immunohistochemical demonstration of GFAP, rats at 2, 5, 12 and 21 days of age were perfused through the heart with a solution of $2 \%$ paraformaldehyde, $0.3 \%$ glutaraldehyde, $0.2 \%$ picric acid in $0.12 \mathrm{M}$, and $\mathrm{pH} 7.6$ phosphate-buffered saline (PBS) (ZAMBONI and De MARTino, 1967). The brains were cut into blocks and postfixed overnight in a PBS containing $2 \%$ paraformaldehyde, and $0.2 \%$ picric acid at $4^{\circ} \mathrm{C}$. After one day washing in a PBS containing $20 \%$ sucrose, $20 \mu \mathrm{m}$ thick coronal and sagittal sections were cut with a cryostat, mounted on slides, and washed with a PBS containing $0.3 \%$ Triton X-100 for 2 days at $4^{\circ} \mathrm{C}$. The sections were preincubated in normal goat serum $(1 / 100)$ for $1 \mathrm{~h}$, and then incubated with a 1: 1000 dilution of the primary antisera against GFAP (Dako Corp. CA, USA) for 2 days at $4^{\circ} \mathrm{C}$. They were washed in buffer and incubated in the diluted biotinylated antibody solution for 60 minutes followed by a buffer wash and then 45-min incubation with Vectastain $A B C$ reagent (Vector Lab., Burlingame, CA, USA). Finally, they were incubated with 3 , 3 '-diaminobenzidine with $0.01 \%$ hydrogen peroxide for $8 \mathrm{~min}$. The control sections were processed similar with GFAP antiserum being replaced with nonimmune rabbit serum. Drawing of GFAP positive cells was done with a drawing tube (Sankei).

For electron microscopy, rats at 3 and 21 days of age were perfused through the heart with $4 \%$ paraformaldehyde, $0.5 \%$ glutaraldehyde, $0.54 \%$ dextrose in $0.1 \mathrm{M}$ phosphate buffer at $\mathrm{pH} 7.4$ (3-day-old animals), and with $1 \%$ paraformaldehyde, $1 \%$ glutaraldehyde in $0.1 \mathrm{M}$ phosphate buffer at $\mathrm{pH} 7.4$ (21-day- old animals). The specimens were postfixed in $1 \%$ $\mathrm{OsO}_{4}$ in $0.1 \mathrm{M}$ phosphate buffer for $1-2 \mathrm{~h}$ at $4^{\circ} \mathrm{C}$, and dehydrated in graded series of ethanol and embedded in Epon. The consecutive, ultrathin sections were observed in an electron microscope.

\section{RESULTS}

In the Nissl stained sagittal sections of rats during their first 3 weeks of age, the subependymal layer composed of darkly stained cell mass around the ependymal layer of the anterior lateral ventricle was found to extend rostralward along the course of the olfactory ventricle to the center of the olfactory bulb where the subependymal layer is surrounded by the granular layer (Fig. 1A). The majority of Golgi stained subependymal cells are bipolar cells with a long leading process tipped by a growth cone and with a short trailing process (Fig. 1B-D). Most leading processes orient towards the olfactory bulb. This means that bipolar cells migrate through the subependymal layer around anterior lateral and olfactory ventricles to the center of the olfactory bulb.

We have observed the arrangement of radial glia in this area with Golgi and GFAP immunohistochemical methods. Golgi preparations of 5-day-old animals revealed the presence of radial glial cells whose spindle-shaped somata are usually connected by short processes to the ventricular surface and whose outer processes extend in a radial direction across the coronal planes of the subependymal layer. They are arranged generally vertically to the ventricular surface in the sagittal sections, i.e., perpendicularly to the direction of the migration of bipolar subependymal cells (Fig. 1E, F).

Fig. 1. A. Photomicrograph of a sagittal section of a Nissl stained 1-day-old rat brain showing a darkly stained cell stream in the subependymal layer ( $S E L)$ from the levels of the lateral ventricle to the center of the olfactory bulb. B. Golgi stained 10-day-old rat brain showing subependymal cell stream. The box is shown at higher magnification in C. C. Higher magnification of subependymal cell stream at the beginning of the olfactory ventricle. Note the leading processes of bipolar cells oriented toward the olfactory bulb. D. A Golgi stained bipolar subependymal cell with a leading process tipped by a growth cone (arrow) and with a short trailing process. E and F. Sagittal sections of a Golgi stained subependymal layer of the anterior wall of the lateral ventricle (E) and around the olfactory ventricle $(\mathbf{F})$ of a 5-day-old rat. Note numerous radial glial cells whose spindle-shaped somata are connected by short processes to the surface of the ventricle and whose outer processes extend at roughly right angles in the direction of the migration of bipolar cells (arrows). $O \mathrm{~V}$ olfactory ventricle. G. Coronal section of the subependymal layer of a 12-day-old rat showing GFAP positive fibers radiating from the olfactory ventricle. $\mathbf{H}$. Sagittal section of the subependymal layer showing GFAP positive fibers disposed generally perpendicularly to the olfactory ventricle. A, B: $\times 20, \mathrm{C}: \times 150, \mathrm{D}: \times 1,000, \mathrm{E}, \mathrm{F}: \times 360$, $\mathrm{G}: \times 480, \mathrm{H}: \times 460$ 
A
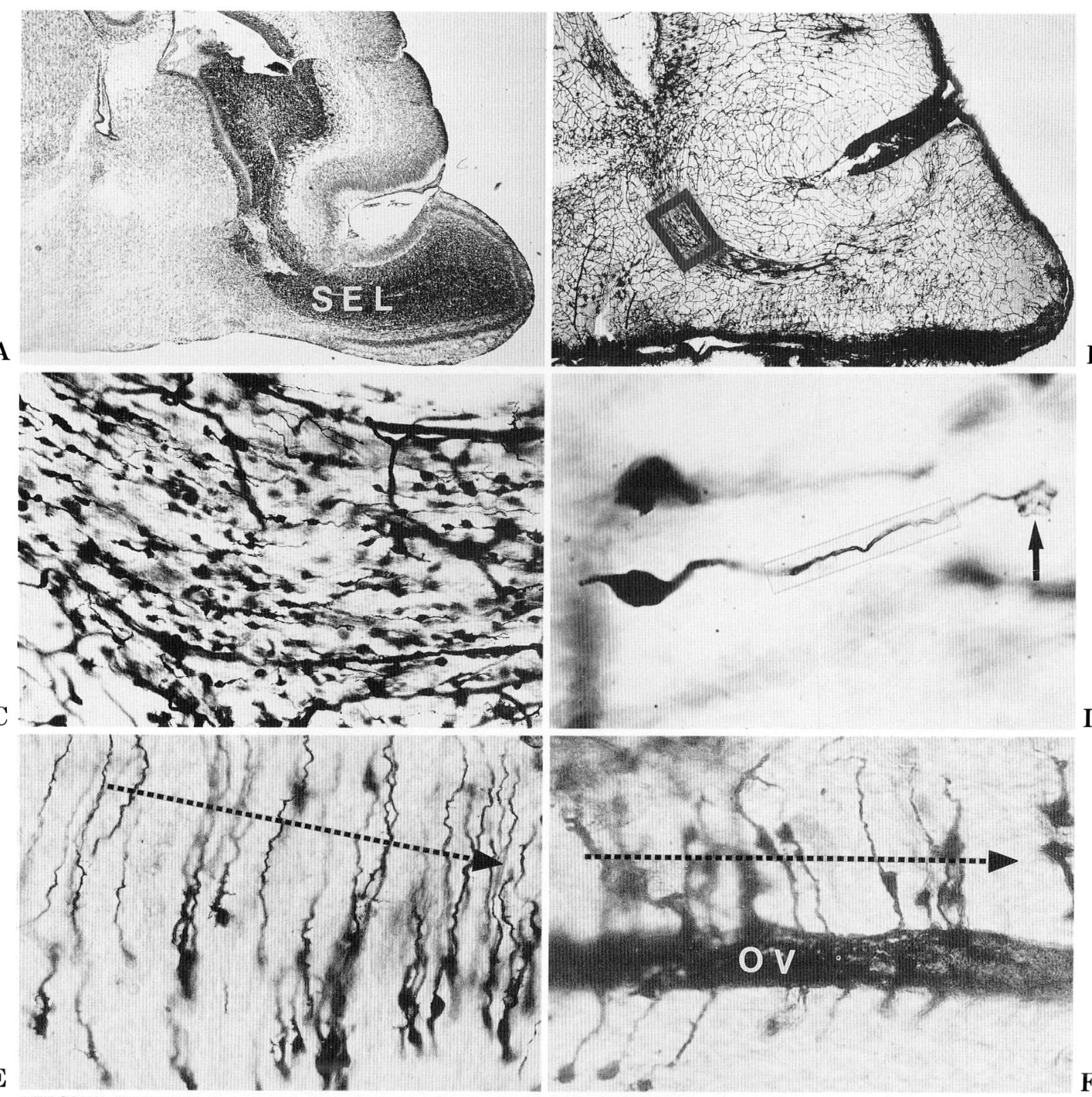

$\mathbf{E}$

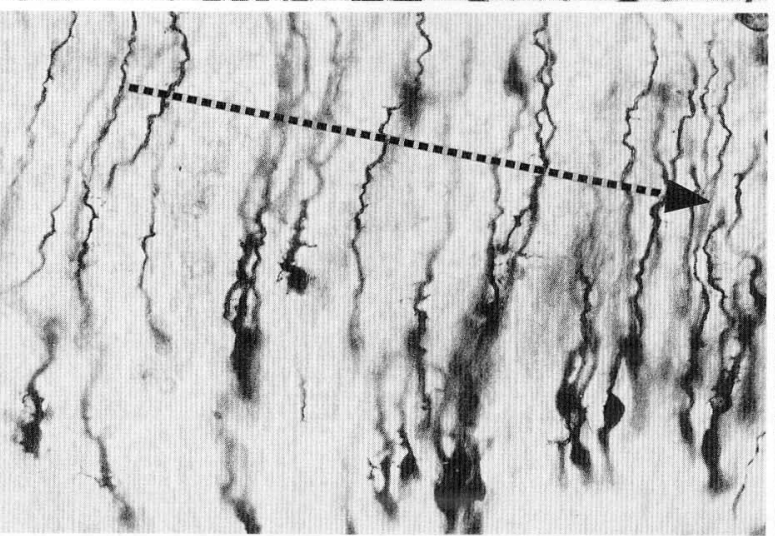

G
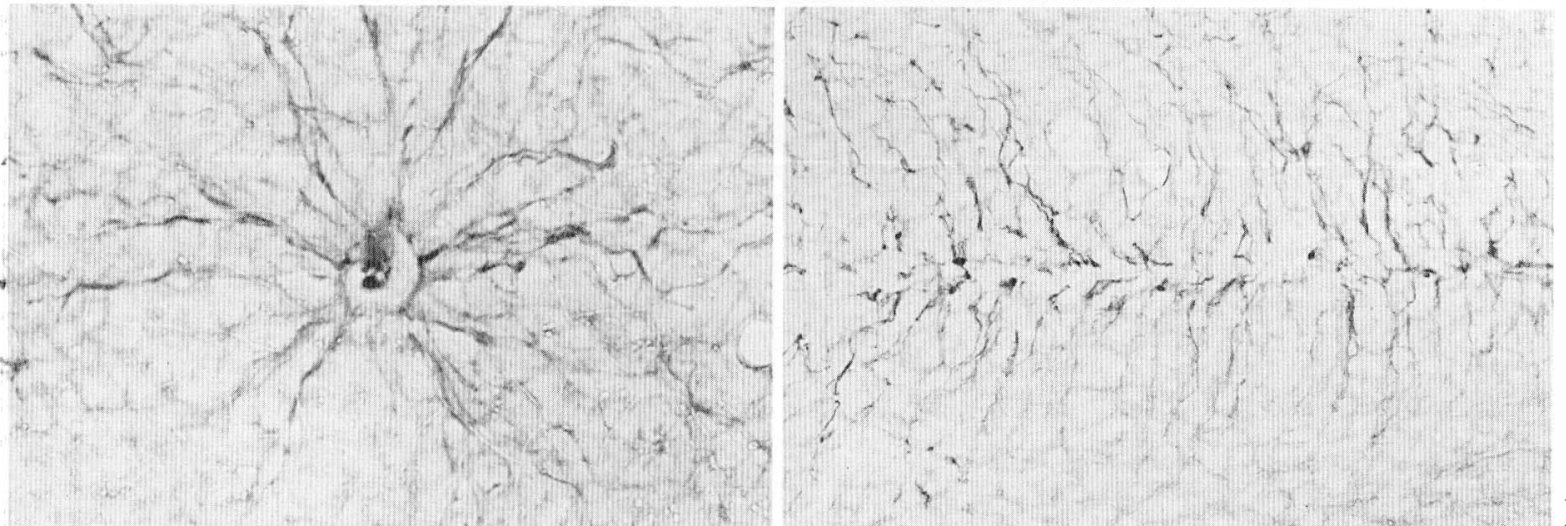

Fig. 1. Legend on the opposite page. 
Immunohistochemical staining of GFAP specific to astrocyte filaments facilitates a more systematic survey of the arrangement of radial glial fibers in this region (LEVITT and RAKIC, 1980). This arrangement is basically similar during the first 2 weeks of age. Figure 2 shows the arrangement of GFAP positive processes in the coronal sections of the subependymal layer of a 5-day-old rat. Radial glial processes diverge centrifugally from the ventricular surface to the periphery of the subependymal layer at each coronal plane of the rostro-caudal extent of the brain.
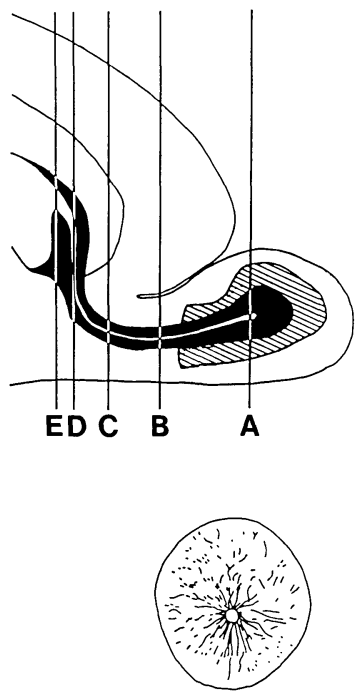

A

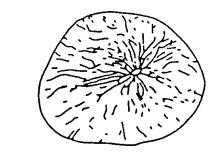

B

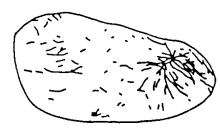

C

Fig. 2. Camera lucida drawings of GFAP positive radial glial fibers in the subependymal layer of a 5-day-old rat. Levels of coronal sections indicated at top left. Drawings A-E represent anterior views of the layer of the left hemisphere.
Numbers of profiles of the nuclei of the subependymal cells can be faintly visualized between the GFAP positive radial glial fibers (Fig. 1G). In sagittal sections of 2-, 5-, and 12-day-old specimens, radial glial fibers are oriented at a right angle to the long axes of the lateral and olfactory ventricles (Fig. 1H), thus being perpendicular to the direction of the migration. In 21-day-old specimens, the basic arrangement of radial glial fibers is largely obscured by clumps of GFAP positive astrocytes.

We have also studied with the electron microscope this topographical relationship in rats at 3 and 21 days of age. The relationship is basically the same in both stages. The round somata of subependymal cells showing a dark appearance with many free ribosomes are revealed among the slender radiating profiles of radial glia appearing more electron-lucent in the coronal sections of the subependymal layer (Fig. 3). On the other hand, in the sagittal sections through the paraventricular planes, lengthwise profiles of subependymal cells with leading processes are situated between the cross-sectioned radial glial fibers (Fig. 4). These findings also suggest that radial glial fibers are arranged perpendicularly to the direction of migration.

In addition, a few axon-like profiles could be found between the subependymal cells in 3-day-old specimens, with significant numbers of them being found in 21-day-old animals. The round profiles of these were directly apposed to some somata of subependymal cells in coronal sections of the subependymal layer. They appear to run pararell to the direction of the migration of the subependymal cells. However, a majority of somata of the subependymal cells had no contact with the axons even at 21 days. We could not find any relationship between the leading processes of the subependymal cells and the axons.

\section{DISCUSSION}

The present report has shown that the radial glial fibers around the lateral and olfactory ventricles are arranged perpendicularly to the route of migration of bipolar subependymal cells, i.e., immature granule cells (Fig. 5). This means that the rostralwards migration of immature granule cells through the subependymal layer does not follow the radial glial fibers, in contrast to many reports that young cortical neurons migrate along the radial glia (for review see CAVINESS and RAKIC, 1978; RAKIC, 1981; SIDMAN and 


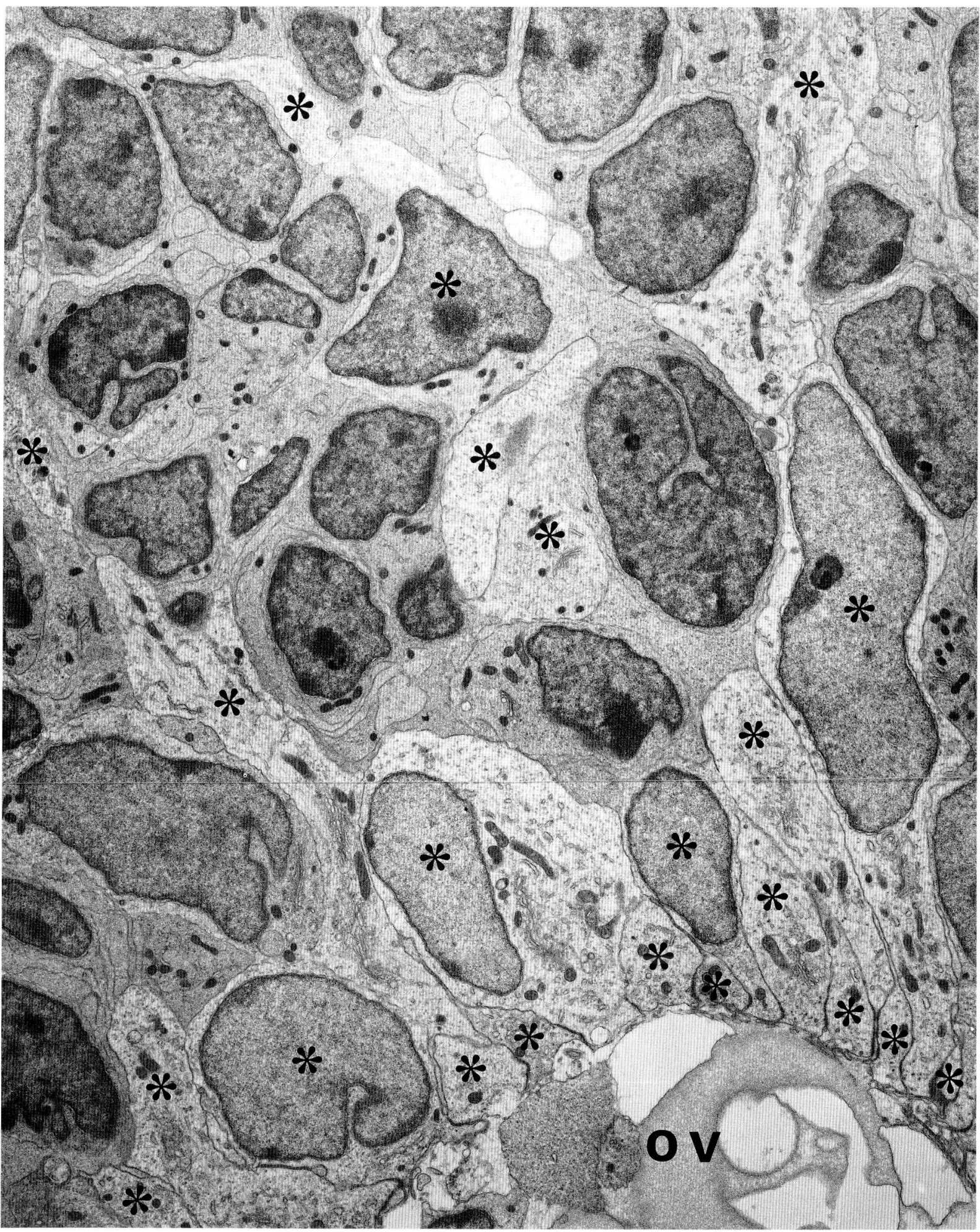

Fig. 3. Electron micrograph of a coronal section of the subependymal layer of a 3-day-old rat. Cross sections of the subependymal cells which appear dark are present among the longitudinal profiles of radial glial cells (asterisks). $\mathrm{OV}$ olfactory ventricle. $\times 4,500$ 


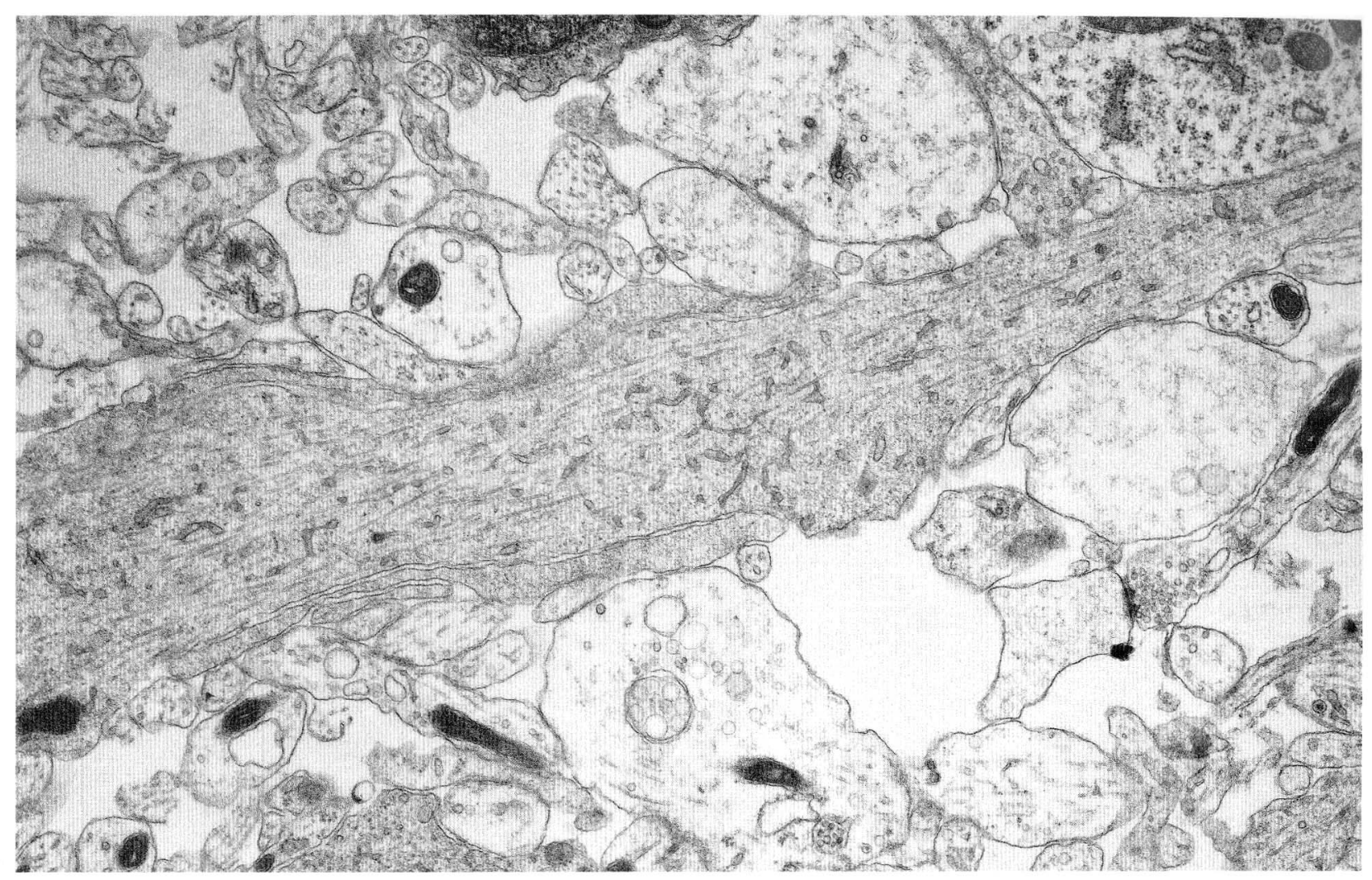

Fig. 4. Sagittal section of the subependymal layer of a 3-day-old rat. A lengthwise profile of the subependymal cell is situated among cross-sectioned radial glial fibers which appear electron-lucent. Note the abundance in the extracellular matrix. $\times 10,000$

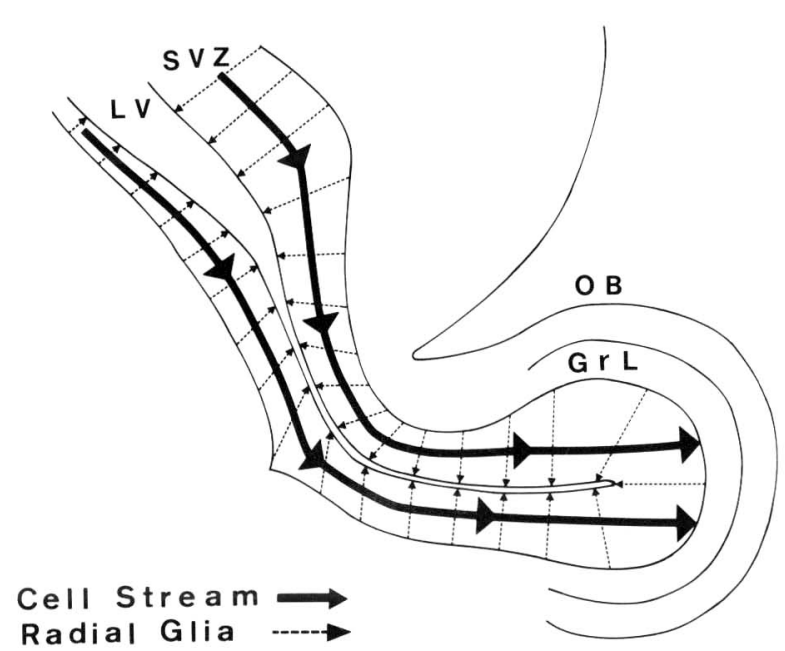

Fig. 5. Diagram showing the relationship between the bipolar subependymal cell stream and the arrangement of radial glial fibers along the anterior lateral and olfactory ventricles. $G r L$ granular layer, $L V$ lateral ventricle, $O B$ olfactory bulb, $S V Z$ subependymal layer.
RAKIC, 1982; ECHENHOFF and RAKIC, 1984).

The cerebellar granule cells have been reported to show two phases of the migration. The first is the primary migration of the precursor of granule cells from the caudato-lateral germinal trigone to the external surface of the cerebellum forming the external granular layer. This migration does not follow the radial glia (SIDMAN and RAKIC, 1982; ALTMAN and BAyer, 1985; Hausmann and Sievers, 1985). The second phase is the migration of the external granule cells that occurs later in development. They follow the radial glia into the depth of the cortex, like gymnasts descending on ropes (RAKIC, 1971a). Our former report (KISHI, 1987) has described two phases of the migration of immature granule cells of the olfactory bulb: the first, rostralwards migration in the subependymal layer; and the second, radial migration from the subependymal layer to the granular layer of the olfactory bulb. The rostralwards migration described in this report appears to correspond to the primary migration of the cerebellar granule cells, because neither of them follows the 
radial glia. However, it should be emphasized that bipolar subependymal cells are considered to be postmitotic neurons from the analyses of mitotic figures and $\mathrm{H}^{3}$-thymidine autoradiography (ALTMAN, 1969; KISHI, 1987; KURODA et al., 1988), while the precursors of the granule cells moving on the surface of the cerebellum are intermitotic stem cells (FUJITA, 1966).

Some investigators have reported that certain neurons migrate along the axonal fascicules (MOODY and Heaton, 1983a, b; Garcia-Segura and Rakic, 1985). The present study has shown axons among the cluster of the subependymal cells at 3 and 21 days. However, we could not draw any definite conclusion on the role of axonal fibers in the migration, because the majority of the subependymal cells have no contact with the axons, especially in early stages of the development.

The cerebellar precursors of granule cells are attached to the basal lamina on the surface of the cerebellum, and appear to use the lamina as a guidance structure for their migration (HAUSMANN and SIEVERS, 1985). Moreover, laminin has been reported to promote the migration of cerebellar granule cells and also the axonal outgrowth of some types of neurons in tissue cultures (MANTHGORPE et al., 1983; SELAK et al., 1983; CoHEN et al., 1987). TORACK and GRAWE (1980) have reported the presence of glycosaminoglycan networks in the extracellular matrix of the subependymal layer in the rat brain. The present electron microscopic study has shown the abundance of extracellar space in the subependymal layer, especially at some distance from the ventricular surface. Our scanning electron microscopic study of this layer (KURODA et al., 1988) has also shown the abundance of extracellular spaces in contrast to the scarcity of the space in the surrounding brain area. These facts imply that bipolar subependymal cells may use the extracellular matrix as a guide for their migration.

Acknowledgements. We are grateful to Mr. A. MASUDA, Mr. Y. IsHIKAWA and Mr. H. TUCHIYA for their technical assistance.

\section{REFERENCES}

Altmann, J.: Autoradiographic and histological studies of postnatal neurogenesis. IV. Cell proliferation and migration in the anterior forebrain, with special reference to persisting neurogenesis in the olfactory bulb. J. Comp. Neurol. 137: 433-458 (1969).
Altmann, J. and S. A. Bayer: Embryonic development of the rat cerebellum. I. Delineation of the cerebellar primordium and early cell movements. J. Comp. Neurol. 231: 1-26 (1985).

Caviness, V. S. and P. RAKIC: Mechanism of cortical development: A view from mutations in mice. Ann. Rev. Neruosci. 1: 297-326 (1978).

Cohen, J., J. F. Burnes, C. McKinlay and J. Winter: The role of laminin / fibronectin receptor complex in the outgrowth of retinal ganglion cell axons. Devel. Biol. 122: 407-418 (1987).

Eckenhoff, M. F. and P. RAKIC: Radial organization of the hippocampal dentate gyrus: A Golgi, ultrastructural, and immunocytochemical analysis in the developing rhesus monkey. J. Comp. Neurol. 233: 1-21 (1984).

Edmondson, J. C. and M. E. Hatten: Glial-guided granule neuron migration in vitro: A high-resolution timelapse video microscopy. J. Neurosci. 7: 1928-1934 (1987).

Fujtta, S., M. Shimada and T. Nakamura: ${ }^{3} \mathrm{H}$-thymidine autoradiographic studies on the cell proliferation and differentiation in the external and internal granular layer of the mouse cerebellum. J. Comp. Neurol. 128: 191-208 (1966).

Garcia-Segura, L. M. and P. Rakic: Differential distribution of intermembranous particle in the plasmalemma of the migrating cerebellar granule cells. Devel. Brain Res. 23: 145-149 (1985).

Hatten, M. E., R. K. H. Liem and C. A. Mason: Two forms of cerebellar glial cells interact differently with neurons in vitro. J. Cell Biol. 98: 193-204 (1984).

- W Weaver mouse cerebellar granule neurons fail to migrate on wild-type astroglial processes in vitro. J. Neurosci. 6: 2676-2683 (1986).

Hausmann, B. and J. Sievers: Cerebellar external granule cells are attached to the basal lamina from the onset of migration up to the end of their proliferative activity. J. Comp. Neurol. 241: 50-62 (1985).

KISHI, K.: Golgi studies on the development of granule cells of the rat olfactory bulb with reference to migration in the subependymal layer. J. Comp. Neurol. 258: 112-124 (1987).

Kuroda, M., K. Murakami, S. Kakuta, H. Tutiya, T. Hashimoto and K. KISHI: On the migration of subependymal cells (In Japanese). Acta Anat. Nippon. 63: 378 (1988).

LevitT, P. and P. RAKIC: Immunoperoxidase localization of glial fibrillary acidic protein in radial glial cells and astrocytes of the developing rhesus monkey brain. J. Comp. Neurol. 193: 815-840 (1980).

Manthorpe, M., E. Engvalli, E. Rouslahrl, F. M. LoNGo, G. E. DAVIS and S. VARoN: Laminin promotes neuritic regeneration from cultured peripheral and central neurons. J. Cell Biol. 97: 1882-1890 (1983).

Moody, S. A. and M. B. Heaton: Developmental relationships between trigeminal ganglia and trigeminal motoneurons in chick embryo. I. Ganglion development is necessary for motoneuron migration. J. Comp. Neurol. 213 : 327-343 (1983a). 
Moody, S. A. and M. B. Heaton: Developmental relationships between trigeminal ganglia and trigeminal motoneurons in chick embryo. II. Ganglion axon ingrowth guides motoneuron migration. J. Comp. Neurol. 213: 344-349 (1983b).

Nowakowski, R. S. and P. RAKIC: The mode of migration of neurons to the hippocampus: a Golgi and electron microscopic analysis in foetal rhesus monkey. J. Neurocytol. 8: 697-718 (1979).

Peters, A. and M. Feldman: The cortical plate and molecular layer of the late rat fetus. Z. Anat. Entw.Gesch. 141: 3-37 (1973).

Pinto-Lord, M. C., P. Evrard and V. S. Caviness, Jr.: Obstructed neuronal migration along radial glial fibers in the neocortex of the reeler mouse: A Golgi-EM analysis. Devel. Brain Res. 4: 379-393 (1982).

RAKIC, P.: Neuron-glia relationship during granule cell migration in developing cerebellar cortex. A Golgi and electronmicroscopic study in macacus rhesus. J. Comp. Neurol. 141: 283-312 (1971a).

: Guidance of neurons migrating to the fetal monkey neocortesx. Brain Res. 33: 471-476 (1971b).

-: Mode of cell migration to the superficial layer of fetal monkey neocortex. J. Comp. Neurol. 145: 61-84 (1972).

-: Developmental events leading to laminar and areal organization of the neocortex. In: (ed. by) F. O. Schmitt, F. G. Worden, G. Adelman and S. G. Dennis: The organization of the cerebral cortex. MIT Press, Cambridge, 1981 (p. 7-28).

RAKIC, P. and R. L. Sidman : Sequence of developmental abnormalities leading to granule cell deficit in cerebellar cortex weaver mutant mice. J. Comp. Neurol. 152: 103-132 (1973).

Schmechel, D. E. and P. RAKIC: A Golgi study of radial glial cells in developing monkey telencephalon: Morphogenesis and transformation into astrocytes. Anat. Embryol. 156: 115-152 (1979).
Selak, I., J. M. Foldart and G. Moonen: Laminin promotes cerebellar granule cells migration in vitro and is synthesized by cultured astrocytes. Devel. Neurosci. 7: 278-285 (1985).

SidmAN, R. L. and P. RAKIC: Neuronal migration, with special reference to developing human brain: A review. Brain Res. 62: 1-35 (1973).

-: Development of the human central nervous system. In: (ed. by) W. HAYAMAKER and R. D. ADAMS: Histology and histopathology of the nervous system. Charles C Thomas, Springfield, 1982 (p. 3-145).

Stensaas, L. J. and S. S. Stensaas: Astrocytic neuroglial cells oligodendrocytes and microgliacytes in the spinal cord of the toad. I. Light microscopy. Z. Zellforsch. 84: 473-489 (1968).

Torack, R. M. and L. Grawe: Subependymal glycosaminoglycan networks in adult and developing rat brain. Histochemistry 68: 55-65 (1980).

Zamboni, L. and C. De Martino: Buffered picric acid and formaldehyde: A new rapid fixative for electron microscopy. J. Cell Biol. 35: 148A (1967).

Prof. Kiyoshi KISHI

First Department of Anatomy Toho University, School of Medicine Omori-Nishi 5-21-16, Ota-ku Tokyo, 143 Japan

岸 清
143 東京都大田区大森西 5-21-16
東邦大学医学部
解剖学第一講座

